II

\title{
A SOUTHERN KURDISH FOLKSONG IN KERMANSHAHI DIALECT
}

\author{
BY E. B. SOANE
}

THE Kurdish dialect of Persian has so far received very little attention from Oriental students, though it fully merits study, for while actually nothing more than a Persian dialect it has not submitted to the erosion which time brings about in every language, and which is so marked a feature in the development of modern Persian. Nor has it been subject to that admixture of Arabic words which has become so great a part of Persian since the invasion of the early Muhammadan Arabs. As a consequence it has preserved intact many words now obsolete in the mother language. Preserved from foreign influence, both by the rude and savage nature of the Kurds and by the inaccessibility of their mountainous homes, the Kurdish tongues (for there are many dialects) present an almost fundamentally pure Persian dialect, though much spoiled by corruption in pronunciation and the abbreviation always accompanying this feature of a language.

Some attention has been bestowed upon Kurdish by Russian scholars within the last four decades, but the dialects brought under notice have been those of the extreme north, notably Kermanji and the dialects of Buyazid in the eastern Caucasus, which show very considerable differences from those of the southern Kurds, who exist as far as Kermanshah, a linear distance of some four hundred miles from their most northerly kinsmen.

Generally speaking, the great belt of high mountain 
lands stretching from the extreme north-west in a wide crescent to the south of Persia has been the conservatory of the old tongue, which in various gradations is found among the wild inhabitants of this region, from the large race of Kurds through Bakhtiāri, Lurī-northern and southern - Kāzerūni in Fars, Dashtistānī, Tangistānī, Minābi to the confines of the Baluch country, each of which forms a connecting link between its northern and southern neighbours in the same way as do the subdialects of Kurdish to those around them.

The dialect here exemplified, as being the most southerly, shows many features which are essentially Kurdish, and many again both common to Kurd and Lur. As the poem here presented is in the Kurdish of to-day, any reference to a Persian word as being obsolete will be to modern colloquial Persian, thus affording a true comparison between modern Kurdish and Persian.

The song is one heard at every gathering in Kermanshah. Its metre is, as is the case with all such poetry, very simple, and varying in some couplets. As the rhyme is confined to the two halves of the couplet, not extending to the preceding and following lines, any number may be added at the will of the singer, and this is in practice very often done. The poem is known as "Qatār-j-Kurdi", qatär being a usual name for any long series of couplets. 
1. Khīāl parkanda, ${ }^{1}$ dil tarfitünam ${ }^{2}$ Chün Farhād, shāhid ${ }^{3}$ i Bisitünam.

Of thoughts scattered, my heart is distressed; Like Farhad, martyr of Bisitün, am I.

2. Khiālī makai ${ }^{1}$ la $^{2}$ tũ düram Mar $^{3}$ mirdin ${ }^{4}$ buwait $^{5}$ nämit la wiram. ${ }^{6}$

Think not that I am far from thee

Unless death take thy name from my memory.

\section{COUPLeT 1.}

${ }^{1}$ parkanda, equivalent of Persian paräganda, parākanda, "scattered," " dispersed."

${ }^{2}$ tarfïtün ( $\ddot{u}$ pronounced as German $\ddot{u}$ ), " distressed," from the Kurdish verb tarfituinin, "to be distressed ;" am is the 1st singular present indicative of the verb "to be". ${ }^{3}$ shähid, signifying a martyr, from the usage of shāhid in connection with the Shi'ah martyrs Husain and Hasan, commonly termed shähid in colloquial Persian.

The last line refers to the well-known tradition of Farhad, who attempted the demolition of the Bisitūn Mountain near Kermanshah in order to gain the hand of Shīrīn.

\section{Couplet 2.}

1 makai, Persian makun, "do not."

${ }^{2}$ la, Persian $a z$, "from."

3 mar, magar, " unless."

"mirdin, Persian murdan, "to die," or verbal noun, "dying."

${ }^{5}$ buwait, Persian bibarad, "that it take." Kurdish infinitive birdin, the root bir having been corrupted to wa, as with the same verb in Luri and southern mountain dialects.

"wiram $=w \bar{i} r+\alpha m$, "my memory." Cf. Ar. wirr, "the mind." 
3. Wa ${ }^{1}$ maīlī yärān qarīb i dil rīsh Wa giān ${ }^{2}$ i Kishbar wa Sāmeranīsh. ${ }^{3}$

By the love of friends near the heart's wound, By the soul of Kishbar in her Sāmera.

4. Wārān ${ }^{1}$ buwārit ${ }^{2}$ batīa ${ }^{3}$ bakai $^{4}$ tar Wa Sāmera chìm ${ }^{5}$ wa māl ${ }^{6}$ i Kishbar.

Let the rain rain and wet my cheek. I go to Sāmera, to the house of Kishbar.

\section{Couplet 3.}

1 wa, Persian bi, the bāyi qasam, "preceding an oath." ${ }^{2}$ giān, Persian jān, "the soul." Giān $i$ Kishbar, "soul of Kishbar," which is a common Kurdish name for a woman.

${ }^{3}$ Sāmeranīsh $=$ Sāmera $+n+\bar{\imath} s h . \quad$ Sāmera, the allusion to a beauty of Samera of Turkestan ; $-i s h$, a possessive termination not necessary to the sense. The medial $-n$ - is purely euphonic.

\section{COUPLET 4.}

1 wārān, Persian bārān, " rain."

2 buwārit, Persian bibāad, "let it rain."

3 batīa, " a cloak."

"bakai, Persian bikunad, "let it make."

${ }^{5}$ chìm, "I go," from Kermanshahi chĩan, "to go," a survival of the ancient chī $\bar{u}$, "going."

${ }^{6} m \bar{a} l$, the Kurdish use for a house. 
5. Māl i dūs bār kird wa nā rezā i dil Allah yārī ${ }^{1}$ büt $^{2}$ manzil wa manzil.

The friend's steed they loaded with unwilling heart God be his friend from stage to stage.

6. Bichīm ${ }^{1}$ wa jākai ${ }^{2}$ Farhād i kihinakan ${ }^{3}$ Bidaìm ${ }^{4}$ wa sarda ${ }^{5}$ riza i pāra $i$ sang.

Let us go to the place of Farhād the mountain-breaker And strike our heads with fragments of stone.*

* i.e. in grief for the friend's departure.

\section{Couplet 5.}

${ }^{1}$ yāri, Persian $y \bar{a} r-a s h=$ " his friend." Kermanshāhī uses $-i$ in place of the Persian genitive termination -ash, " of him, her, it."

${ }^{2} b \bar{u} t$, Persian bäshad, "may he be," from infinitive bian, " to be."

\section{Couplet 6.}

1 bichìm, "let us go;" see note 5 to couplet 4 .

${ }^{2} j \bar{a} k \alpha=$ Persian $j \bar{a}, " a$ place."

${ }^{3}$ kihinakan, Persian kühän kan, the breaker of mountains.

4 bidaīm, " let us strike," from $d \bar{a} n$, " to strike," root $d a$. ${ }^{5}$ sarda, Persian sar, "head," or "heads". The affix -da occurs in Kurdish nouns; usually placed in an objective or a noun preceded by a preposition. 
7. Agar Musalmānī rām ${ }^{1}$ la $^{2}$ jāmita ${ }^{3}$

Zardi o zaifïm ${ }^{4}$ paĩ $^{5}$ shamãmita. ${ }^{6}$

If thou be a Musulman, mercy is in thy garments.

My pallor and weakness are because of thy delicacy.

8. Yeh ${ }^{1}$ chi dardì bī, ${ }^{2}$ bĩ wa duchäram

Sar bī wa sālār, ${ }^{3}$ lash ${ }^{4}$ bī ${ }^{5}$ wa bāram.

What malady was this, it was from our meeting.

My brain is swelled, my body dead with my load (of love).

\section{Couplet 7.}

${ }^{1}$ rām, Persian rahm, "mercy."

${ }^{2} l a$, Persian $b i, a z$, dar, " in."

${ }^{3} j \bar{a} m i t a=j \bar{a} m-\alpha t-\alpha s t$, " is in thy garments."

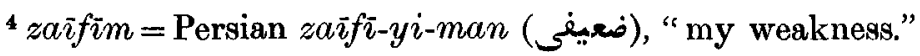
${ }^{5}$ paī, "for," "because of." This is still used as most

Persian dialects and in old Persian.

"shamāmita = shamōm-at-ast, "thy delicacy is."

\section{COUplet 8.}

$"$ yeh = Persian $\bar{\imath} n$, "this."

${ }^{2} b \bar{\imath}$, Persian $b \bar{u} d$, "was ;" the past tense used in a present sense, as is common both in Kurdish and vulgar Persian. 3 sālār, "swelled."

4 lash, Persian lāsh, "dead," "a corpse."

s bìm, Persian shudam, "I became." The Kurds have no proper distinction between the verbs "to be" and "to become". 
9. Nishī ${ }^{1}$ wa zhangit ${ }^{2}$ manit $^{3}$ wa jarda ${ }^{4}$ Manit wa sepāi tāzeh fath karda.

Thy lashes and eyebrows are like a robber,

Like an army newly come from victory.*

* The metaphor is that of the lashes and eyebrows being like the lances and bows of an army.

10. Cha bikam ${ }^{1}$ wa dast i yeh naō namāma ${ }^{2}$ Shaō ${ }^{3}$ la pazhäraī ${ }^{4}$ khaō $^{5}$ l'ỉm ${ }^{6}$ haräma.

What can I do at the hand of this fresh beauty?

At night, from thought of her, sleep is forbidden me.

Couplet 9.

${ }^{1} n \bar{\imath} s h \bar{\imath}$, "eyelashes," Persian muzha.

${ }^{2}$ zhangit, "thy eyebrows."

${ }^{3}$ mañ̄t, Persian mimānad, idiom for " resembles".

${ }^{4}$ jarda, "a robber."

\section{Couplet 10.}

${ }^{1}$ bikam, Persian bikunam, " may I do."

${ }^{2}$ nā̄ namāma, "fresh beauty."

3 shā, Persian shab, "night."

${ }^{4}$ pazhārai, "prepossession of her," "thoughts of her."

${ }^{5}$ khāo, Persian khwāb, "sleep."

${ }^{6}$ '' $\mathrm{i} m=l a+\bar{\imath}+a m$, Persian az man, "from me." The junction of the two short $a$ 's in $l \alpha$ and $a m$ usually produces in Kurdish one long $\bar{\imath}$ sound. 
11. Ham kaft ${ }^{1}$ wa wiram ${ }^{2}$ khāsī $^{3}$ yi Shaukat Shīrīnī yī annām ${ }^{4}$ zhīr i kulkwat. ${ }^{5}$

Also fell to my mind the goodness of Shaukat, The sweetness of her figure under her tunic.

12. Khānum khānumān bān ${ }^{1}$ wa 'amārat Wa pām mashq makat, ${ }^{2}$ wa chaō ${ }^{3}$ ishārat.

The lady of ladies upon her housetop

Dances for me with her feet, and beckons with her eyes.

\section{Couplet 11.}

1 kaft, "fell," from Kurdish verb kaftin, " to fall."

${ }^{2}$ wìram, "my memory." See note 6, couplet 2.

3 khāsi, "goodness," Arabic خاض. The Persian word $k h \bar{u} b$ is seldom used in Kurdish.

${ }^{4}$ annām, obsolescent Persian andām, "form," "stature."

${ }^{5}$ kulkwat, the Kurdish woman's garment, a kind of tunic, with full pleated skirts, also called kulanja and kamarchinn.

\section{Couplet 12.}

${ }^{1} b \bar{a} n$, Persian $b \bar{a} m$ and $b \bar{a} l a$, " up," " above."

¿ wa pām mashq makat, a Kurdish idiom for the Persian $b \bar{a} p \bar{a}$ nashq mīkunad barāyi man. This occurs but rarely, however, in such an involved phrase. In some Persian dialects the sentence, while preserving the same idea of a possessive pronominal termination instead of a separate pronoun and preposition, would read $b \bar{a} p \bar{\alpha}$ mashqam mīllunad.

${ }^{3}$ chā̄, Persian chashm, "eyes." 
13. Dam ${ }^{1}$ gird a mam ${ }^{2}$ gird, pisht i pāshna ${ }^{3}$ gird Masī ${ }^{4}$ yi chaōwakat ${ }^{5}$ min ${ }^{6}$ la dunyã bird.

Round mouth, round breast, round heel, Intoxication of thy eyes took me from this world.

14. Har chan ${ }^{1}$ manīshim ${ }^{2}$ sāl dumätir ${ }^{3}$ Khwashimm ${ }^{4}$ kam mau ${ }^{5}$ talkhìm ziātir. ${ }^{6}$

The longer I remain succeeding years

My pleasure decreases, my bitterness grows more.

\section{Couplet 13.}

1 dam, Persian dahan, "mouth."

${ }^{2}$ mam, "the breast." Though no recognized Persian equivalent exists, the words mimeh, mām, and one or two other variants occur in the same sense in the South Persian and Lur dialects.

${ }^{3}$ pisht $i$ pāshna, Persian pusht i pāshneh, "the heel." ${ }^{4}$ masi, Persian mastī, "intoxication."

${ }_{\text {: }}^{5}$ chao wakat $=c h a \bar{o}+a k+a t$, "thy eyes." The termination $-a k$ is as common in Kurdish as in vulgar Persian for all nouns.

"min, Persian man, "me," "I."

\section{Couplet 14.}

${ }^{1}$ har chan, Persian har chand, "however much."

2 manishim, Persian minnishinam, "I sit," "remain." The verbal form with initial $m$ is hardly correct Kermanshähī, which as a rule omits any prefix in present indicative. ${ }^{3}$ dumātir = Persian dumbältar, "later," "more behind."

The word dumbāl is now little used except in the dialects of Yazd and Isfahan.

${ }^{4}$ khwashīm, Persian khüshī-am, "my pleasure."

5 maü, Persian mishavad, "becomes."

${ }^{B} z \bar{\imath} \bar{a} t i r$, Persian zīãdtar, "more." 
15. Khānumī la mulk i Kalhur ${ }^{1}$ kirdia $^{2}$ tür $^{3}$

Dinān ${ }^{4}$ chün sadaf, qāmat chün bulür.

A lady from the Kalhur land has quarrelled,*

(Her) teeth like mother of pearl, her stature like crystal.

* i.e. quarrelled and run away from the Kalhur.

16. Khānum tuna ${ }^{1}$ Ali, chomas, ${ }^{2}$ tuna Dāūd

Pichakat ${ }^{3}$ lāwa ${ }^{4}$ ta bünam ${ }^{5}$ chaōwat. ${ }^{6}$

Lady, for Ali's sake-(thou of love) frenzied eyesfor David's sake,

Remove thy veil, that I may see thy face.

Couplet 15.

${ }^{1}$ Kalhur, a large district and tribe of Kurds west of Kermanshah, noted for their ferocity and power.

2 kirdia, Persian karda ast, " has made," "done."

${ }^{3}$ tür, "quarrel." The verb here inverted is the compound tür kirdin, a parallel to Persian qahr kardan, " to quarrel," " to take offence at."

${ }^{4}$ dinān, Persian dandān, "teeth."

\section{COUPLet 16.}

${ }^{1}$ tuna, Persian tur, "for the sake of." Tuna also occurs in Luri and South Persian dialects.

${ }^{2}$ chomas, Persian chashm-mast, " frenzied."

${ }^{3}$ pichakat, Persian picha-at, the small square black horse-

hair veil worn by the women of Kermanshah and

Turkish Arabia out of doors.

" lāwa, " take off," "remove," inf. lāwān.

s bünam, Persian bibinam, "let me see."

${ }^{6}$ chaōat, Persian chashmat, "thy eyes." 
17. Min ki sufīm sāf ${ }^{1}$ taōba kirda bīm ${ }^{2}$ Qamar sima ${ }^{3} \operatorname{dim}^{4}$ imän harda bìm. ${ }^{5}$

I who am a Sūfī had entirely renounced (Sufism).

(When) I saw the silvery moon I was released from faith.

18. Kāfir küshtitam ${ }^{1}$ magar khünitam ${ }^{2}$

Kushtai khālakaī ${ }^{3}$ chāli ${ }^{4}$ tanitan. $^{5}$

Pagan, thou hast slain me, am I at feud with thee ?

Killed (am I) by the mole in the hollow of thy neck.

\section{COUplet 17.}

${ }^{1} s \bar{a} f$, Persian صاف, "smooth," here used in the sense of "entirely".

2 bìm, Persian būdam, "I was."

3 sìmā, Persian sīmāb, "quicksilver," "silver."

${ }^{4} \boldsymbol{d} \bar{\imath} m$, Persian $d \bar{\imath} d a m$, Kurdish inf. dīan.

${ }^{5}$ harda bìm, "I was released ;" Kurdish harda bian, "to be released," "to be free."

\section{COUplet 18.}

${ }^{1}$ küshtītam, Persian kushtī marā, vulgar Persian kushtīm, "thou slewest me."

${ }^{2}$ khünitam, Persian khūnī-at-am, "am I at blood-feud

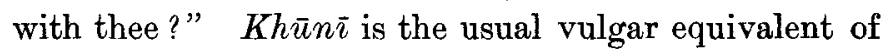
khündārī, "a blood-feud."

${ }^{3}$ khālakā, Persian khāl, "a mole."

" chāl, "a hollow, depression," obsolescent Persian.

${ }^{5} \tan \bar{\imath} t$, Kermanshāhi $\tan \bar{\imath}$, " the neck," the lower part of the throat. 
19. Khälì wa tū naìm ${ }^{1}$ mar $^{2}$ wa Sekīna . Humā ${ }^{3}$ kūtasaī ${ }^{4}$ wa takht $i$ sīna.

A mole like thine I never saw, except on Sekina; She had moulded it upon the breadth of her breast.

20. Dastam bikishīn ${ }^{1}$ wa kur ${ }^{2}$ giānī $^{3}$ Wa māli ${ }^{4}$ dūs ${ }^{5}$ chïm ${ }^{6}$ sha ${ }^{7}$ wa mïmāni. ${ }^{8}$

Lead me by the hand, me of little strength; To the lover's house let us go to-night to the feast.

\section{Couplet 19.}

${ }^{1}$ naim, Persian nadidam, "I saw not."

2 mar, magar, "except."

${ }^{3} h u m \bar{a}$, Persian $\bar{u}$. The word is unusual in Kermanshāhi dialect, properly belonging to that of Sina of Kurdistān. ${ }^{4} k \bar{u} t a s a \bar{\imath}$, Persian $k \bar{u} b \bar{\imath} d a$ ast, "is, or has, hammered" (pounded, moulded).

\section{Couplet 20.}

${ }^{1}$ bikisshinn, Persian bikashĩd. Inf. kisshin, "to pull," "draw." ${ }^{2}$ kur, "feebleness."

${ }^{3}$ giān, Persian jān, "body," "soul ;" kur giānī, " bodily weakness."

" $m \bar{a} l$, Kurdish use of the Arabic word for "house".

${ }^{5} d \bar{u} s$, Persian $d \bar{u} s t$, "friend," "lover."

${ }^{6}$ chim, "let us go;" see note 5 , couplet 4.

${ }^{7}$ sha, Persian shab, "night."

8 mìmāñ, Persian mihmänī, "a feast," "banquet." 
21. La Sari Mìl $^{1}$ banürī $^{2} K_{\text {erind diyāra }}{ }^{3}$

Har kas dūs dirit ${ }^{4}$ chāo intazāra.

From Sar i Mil, by her light, Kerind is visible.

Who has a lover sits with expectant eyes.

22. La düro ${ }^{1}$ hätim ${ }^{2}$ bishnāsa ${ }^{3}$ dangam ${ }^{4}$

Garta ${ }^{5}$ qarïbì nishtīa ${ }^{6}$ la rangam. ${ }^{7}$

I am come from afar, hear my cry;

The dust of strange (lands) has settled upon my face.

\section{COUPLET 21.}

${ }^{1}$ Sar-i-Mil, the remains of an old pillar set to mark the road from Harunabad to Kerind (near Kermanshah) and distant from the latter about 5 miles.

${ }^{2}$ banürī, Persian bi nürash, " by her light."

${ }^{3}$ diyāra, "is apparent."

"dirit, Persian dārad, "he has."

\section{COUPLET 22.}

1. düro, Persian dūr, "afar."

${ }^{2}$ hātim, Persian $\bar{a}$ madam, Kurdish infin. hätin, "to come," this form having arisen from the preservation of the older Persian verb āidan, " to come," to which $h$ has been prefixed, as often occurs with similar words in Kurdish.

"bishnāsa, Persian bishinās or bishinū, " hear!"

4 dangam, Persian bāngam, "my cry."

"gart, Persian gard, "dust."

${ }^{6}$ nīshtīa, Persian nishasta ast, "is sitting," "settled upon,"

Kurdish inf. nishtin.

7 rangam, "my colour," here used for " face". 
23. Kamarchīn ${ }^{1}$ i makhmal, gūshwārān wa gūsh Mirda ${ }^{2}$ la mazär tiārat ${ }^{3}$ wa hūsh.

Her tunic is of velvet, earrings in her ears, The dead from the tomb she brings to life.

24. Lāil bām ${ }^{1}$ la zwān ${ }^{2}$ paī ${ }^{3}$ Laìlì nāmì Khāl dānai ferang, ${ }^{4}$ zulf dasta i dāmī. ${ }^{5}$

May I be dumb of tongue, of one named Laili (Her) mole (is) of rare beauty, her locks a cluster of nets.

\section{Couplet 23.}

1 kamarchīn; see note 5, couplet 11.

2 mirda, Persian murda, "the dead."

${ }^{3}$ tīarat. Persian mīärad or mīâvurad, "she brings." Kurdish infinitive äwirdin and hawwirdin. This verb, together with hātin, takes prefixial $t \bar{\imath}$ in Kermanshāhi in the present indicative, a variant of the similarly used $d i$ and $d \alpha$ in more northern dialects.

\section{Couplet 24.}

1 bām, Persian bāsham, "may I be."

${ }^{2} z w \bar{a} n$, Persian zabān, "tongue."

${ }^{3}$ pai, Persian barāyi, "for."

${ }^{4}$ danai ferang, a term used in Kurdish to express any small article of great beauty.

${ }^{5}$ dasta $i d \bar{a} m \bar{\imath}$, a cluster of nets (for the ensnaring of the enamoured), a common Persian metaphor. 
25. Banā kird ghārat i sarmāya i hūsham Lungi Majnūnì aō da $\bar{a}^{1}$ wa dusham.

She undertook the plunder of my stock of sense, The cloth of Majnūn she gave me for my back.*

* i.e. she made me like Majnūn, mad for love of Laĩlĩ.

26. Chan ${ }^{1}$ jaur chan jefā, chan khākisāri

Shwān ${ }^{2}$ i bì muz ${ }^{3}$ u haqq nā diyārì.

How much trouble, how much anguish, how much lamenting?

Nights without reward, and right unrecognised!

27. Sa jwōām $\mathrm{ka}^{1}$ ta dil nīā ${ }^{2}$ būm ${ }^{3}$

Kam das ${ }^{4}$ la dāmām Shaikh o mulla būm.

Then release me that my heart be at rest,

That my hand be not stretched out to skirts of Mulla and Shaikh!

\section{Couplet 25.}

${ }^{1} d \bar{a}$, Persian $d \bar{a} d$, , gave."

Couplet 26.

${ }^{1}$ chan, Persian chand, used in Kurdish indifferently for "how much" and "how many".

${ }^{2}$ shwān, Persian shabān, "nights." This plural for shab is obsolete in Persian.

${ }^{3}$ muz, Persian muzd, " reward," "price."

\section{Couplet 27.}

${ }^{1}$ sa jwōam ka, Persian pas javābam kun, "then make me my reply," i.e. "release me".

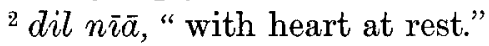

3 bum, Persian bishavam, "that I become."

"das, Persian dast, "hard." 
28. Fedāī mālakai ${ }^{1}$ pāyi Paraōit ${ }^{2}$ bām ${ }^{3}$ Fedai dìdakai ${ }^{4}$ shāo bī khaōit ${ }^{5}$ bām.

May I be the sacrifice of thy house at Paraō's foot, Sacrifice of thy eyes upon sleepless nights.

29. Har ${ }^{1}$ tīait ${ }^{2}$ har chìt $^{3}$ cham $^{4}$ wa gilāwa ${ }^{5}$ Chün kaok ${ }^{6}$ i nisār khīāl wa hilāwa. ${ }^{7}$

(Thou) ever coming, ever going, with straining eyes, Like a partridge of the desert rising to fly.

\section{Couplet 28.}

${ }^{1}$ mālakai, "a house," the termination -akai being quite optional and ruled by no custom.

2 Paraōit, "thy, Paraō," the possessive referring to mālakai in conformity with Persian usage, when a possessive is added to the last of a series of nouns used adjectivally. Parao is a high range of mountains north-west of Kermanshah.

${ }^{3} b \bar{a} m$, Persian bāsham, " may I be." See note 1, couplet 24. 4 dĩlakai, Persian dĩda, "eyes."

5 khaöit, "thy, sleep," the possessive qualifying diddakai.

\section{COUPLET 29.}

${ }^{1}$ har, the same word as in Persian, but possessing in

Kurdish a wider meaning, here signifying "incessantly". 2 tĩa $\bar{\imath} t$, Persian $m \bar{\imath} \bar{a} y \bar{\imath}$. See note 3, couplet 23.

3 chìt, Persian mìravī, "thou goest."

"cham, Persian chashm, "eyes."

${ }^{5}$ gila $w$ w, "tiredness, straining." The word is gil $\bar{a}$ with termination - $a w a$ or $-w a$, which is frequently added in

Kurdish poetry.

${ }^{6} k \alpha \bar{o} k$, Persian $k a b k$, "partridge."

7 hilāwa, "flying," " rising." 
30 Chaōm kaft ${ }^{1}$ wa zīd u māwān ${ }^{2}$ i Laìli

Anūm ${ }^{3}$ jüsh hāwird, ${ }^{4}$ gīriyām ${ }^{5}$ khaīlï.

My eyes fell upon the place of Laili ;

My grief came to boiling, and my tears many.

31. Min ki Kerind shār ${ }^{1} \operatorname{dìm}^{2}$ wa wìrāna ${ }^{3}$

Sar i Pul ${ }^{4}$ dīm wa jāy bāyaqush ${ }^{5}$ khāna.

I (who) have seen Kerind town a ruin,

And Sar i Pul the place of owls' nesting.

The word $k i$ is here not necessarily to be translated as a relative pronoun, being used in an emphatic sense, which is a common use in vulgar Persian as in Kurdish, as Persian man ki chand martaba guftam? "how many times have I spoken?"

Couplet 30.

${ }^{1}$ kaft, Persian uftād, "fell," from Kurdish inf. kaftin, "to fall."

${ }^{2} z \bar{\imath} d u m \bar{a} w \bar{a} n$, a Kurdish expression somewhat equivalent to the Persian maqām va makān, "residence and place." "an ūm, Persian andūh-am, "my grief."

${ }^{4}$ hawwird, Persian avvard, "brought." ${ }^{5}$ gīriy $\bar{\alpha}$, Persian girī $\bar{\alpha}$, "tears."

\section{Couplet 31.}

${ }^{1} \operatorname{sha} r$, Persian shahr, "a town."

${ }^{2} d \bar{\imath} m$, Persian $d \bar{\imath} d a m$, "I saw."

3 wīrāna, Persian vīrān, "ruin," a now obsolete word.

${ }^{4}$ Sar i Pul, or more correctly Sar i Pul i Zohāb, near the Perso-Turkish frontier post of Qasr i Shirin, a Kurdish town.

${ }^{5}$ bāyaqush, "an owl" (Turkish). 